\title{
Kyai and Power in Banten, Indonesia
}

\author{
M. Dian Hikmawan ${ }^{1}$, M. Rizky Godjali², Ika Arinia Indriyany ${ }^{3}$ \\ ${ }^{123}$ Government Department, Universitas Sultan Ageng Tirtayasa \\ dian.hikmawan@untirta.ac.id, rizky.godjali@untirta.ac.id, ikaarinia@ fisip- \\ untirta.ac.id
}

\begin{abstract}
In Indonesian socio-cultural society, Kyai is an important indicator to perceive the diversity of the socio-cultural. Kyai is not only a leader in religious rituals but also kyai also be used as symbols in political roles. This research tries to elaborate on the role of Kyai in political structuration in Banten,. This research tries to analyze cultural aspects to elaborate on the socio-political function and role of the Kyai, it becomes a very interesting matter for further review. Therefore, these studies involve the role of Kyai in political Power in Banten. by using a phenomenological approach in understanding the realities that occur in Socio-cultural. This research was conducted to understand, first, understanding and interpretation this by using the structure of society in Banten to understand the role of Kyai in socio-cultural, how the agent perceives the political agenda. Secondly, morality or the right direction, it is means how the influences of morality to the political decisions on the socio-cultural agenda. Third, power relation, how to perceive regulation on the socio-cultural and its influence on government policies in Banten
\end{abstract}

Keywords: Kyai, Power, Socio-Cultural, Social Change

\section{Introduction}

Kyai with all existence has become a symbol of the social agenda politics in Banten, even shifting between Champion and the Ulama (religious scholars) become an interesting study, at least can be traced from some literature from research (Hamid, 2010) about the process of marginalization of the political role of the clergy on the one hand and the domination of warlords on the other hand, both the functions, responsibilities, gait, also in mindset. Basically gait Kyai is not only seen from the excitement of transforming religious values in society, but also on sociopolitical persistence in the struggle alone. See figure Kyai, then that is in our minds is: First, as founder boarding schools, that schools can be said to be aspects that are almost always in the development of society, especially concerning the influence of Kyai.

Kyai schools are those whose daily activities teach religious sciences in schools, both in formal educational institutions and non-formal schools and other programs. Second, as a teacher of the congregation, as the leaders of prayer groups. Third, as defenders of the ummah, as a preacher, and others. In the context of Kyai as a preacher, Kyai becomes a figure of inspiration to his community, so that in the totality of a preacher must be professional. As a social construction, the concept of Kyai certainly different for each community, including in Banten. Kyai concept for society Banten become a symbol of the continuity of the existing culture. the influence of a traditional agrarian culture that characterizes the lives of the vast majority of Banten gives meaning and value appreciation of Kyai higher. 
Historically, Kyai is part clerical position figure quite encouraged within the context of the various considerations concerning policies, especially policies that involve the community, especially when dealing with the needs and mobilization movements. Then Kyai assessed and placed as a determinant of progress and whether or not a civilization. Therefore, progress is always synonymous with change, then arises whether Kyai first accusation to be changed or society. Kyai is required to perform a variety of breakthroughs in conveying values and symbols. Traditional lifestyle agrarian society Banten contribute greatly to the preservation of local wisdom values compared to other regions were more modernist Banten and metropolis (Muslim, Kolopaking, Dharmawan, \& Soetarto, 2016). For that understanding of the community, Kyai In Banten had a much deeper meaning than just a group of people who are considered to have any depth of knowledge of Islamic teachings. Kyai had much to do movement even struggle, one through its political role by carrying various Islamic parties. Kyai figure is quite encouraged within the context of the various considerations concerning policies, especially policies that involve the community, especially when dealing with the needs and mobilization movements.

Then Kyai assessed and placed as a determinant of progress and whether or not a civilization. Therefore, progress is always synonymous with change, then comes the accusation whether Kyain first to be changed or society (Yasin, 2016). The allegation was then placed in a variety of interests when Kyai was always placed as the guardian of a tradition that should be stagnant and not dynamic so that conflicts of social change must be addressed in the name of religion. Or vice versa, Kyai which should be in the vanguard of the front to adjust to various upheavals changes due to the demands of the times. The position makes Kyai are in important strategic (Abdussalam, 2015).

\section{Kyai, Power and Political Impact}

Roles are participation in contributing to or contributing to the activities or developments in political and social life. (Linton, 1956) describes the role of the dynamic aspects of status. A role is a behavior that is expected of a person occupying the role becomes an active verb and contributive. The role of being a set of behaviors that are expected by others of one's corresponding position in the system. Thus the role is very strongly influenced by the social situation both inside and outside and is stable. A role is a form of behavior that is expected in certain social situations. According (Soekanto, 2007) the role of the dynamic aspect of the position. Between the role and the position can not be separated for each other to have a mutual dependence. Someone said to perform a role when he was exercising its rights and its obligations. In the roles there are two (2) kinds of expectations are the expectations from the public on the role holder or the obligation of stakeholders and expectations that are owned by the holder of the role of the community or on people related to him.

Everyone has a variety of roles derived from the patterns of social life. It was at once means that the role of determining what he had done for the community and what opportunities are given by the people to him. The importance of the role of a community is because he set the behavior of someone who is at the same time in certain limits can be a resource in predicting the actions of others (Arinia, Hikmawan, \& Ma'asan Mayrudin, 2019). The person concerned will be able to adjust to the group of their behavior. The role more points to the function, adjustment, and as a process. According to Levinson's role may include three things:

1. The role includes norms connected person in society. The role in this sense is a series of rules that guide a person in public life 
2. The role is a concept of what can be done by individuals in the community as an organization

3. The role can also be regarded as individual behavior that is important to the social structure of society According (Soekanto, 2007) in Indonesia there is a tendency to emphasize the position rather than the role.

The term 'Kyai' has much in common with the ulama, although sometimes there are significant differences. The word 'ulama' is the plural of 'alim meaning 'people who have knowledge'. In the original context, ulama means scientists in a social, religious, or cultural sense. In the Quran, the cleric is not the predicate of monopoly for interpreters, hadith, figh, Sufism, and so on which is called al-'ulum al-diniyyah religious sciences (Noeh \& Othman, 2012)"

This is thought to be due to a strong tendency to emphasize the value of materialism than spiritualism. Value materialism in most cases measured on the attributes or characteristics of certain outward like titles, honors, luxury homes, vehicles, uniforms, and so forth. Kyai the social status of a person which in itself is attached to a variety of roles. One of the roles held by Kyai is your role as a leader in the midst of the cultural community. Because outside the formal structures of government, the Kyai can be categorized as an informal leader (Jannah, 2015).

As a center of propaganda, Kyai quite a lot of contributions in shaping the life of society, it is very influential in government policy since the Dutch colonial era to the present. Likewise with modern Indonesian civilization, that spearheaded the development of the Malay archipelago civilization contained in Kyai existence itself. Kyai be the main actors of all social conception of religion as well as an institution, so Kyai had a significant influence on the development of the social, political, and economic, especially for local communities (Noeh \& Othman, 2012). It can be said that the Kyai and their influence in it become a pattern-forming system in community life, but it also can be a determinant of culture Kyai is currently not only dominant in the religious social development of society, but also involved in politics and bureaucracy. Confidence in the Kyai compared to the other leaders, according to (Noeh \& Othman, 2012) is seen that the orientation of the rural population is Kyai and not on bureaucratic leadership. That's because Kyai has its own charisma that is hardly owned by other leadership.

So, Max Weber thought that the patrimonial structure which is based on the charisma of the ruler is the main factor of the cultural system of Islam, so we need a charismatic and sacred ruler to be a leader or ruler. While the authorities are patterned to be a smart guard of honor and the trust of his people. not the bureaucratic leadership. That's because Kyai has its own charisma that is hardly owned by other leadership. So, Max Weber thought that the patrimonial structure which is based on the charisma of the ruler is the main factor of the cultural system of Islam, so we need a charismatic and sacred ruler to be a leader or ruler. While the authorities are patterned to be the smart guard of honor and the trust of his people. not the bureaucratic leadership. That's because Kyai has its own charisma that is hardly owned by other leadership. So, Max Weber thought that the patrimonial structure which is based on the charisma of the ruler is the main factor of the cultural system of Islam, so we need a charismatic and sacred ruler to be a leader or ruler. While the authorities are patterned to be the smart guard of honor and the trust of his people.

\section{Method}

The method used in this research is a descriptive qualitative method. This kind of research will generate descriptive data on oral and written words and behavior of 
people. The average results of his research are the description of a phenomenon in different contexts so that the conclusions of each - each individual will vary depending on the viewpoint used. While the approach used is the phenomenological approach. in particular hermeneutic phenomenology into a selection method that the researchers use, because phenomenology hermeneutic open space for authors in conducting research on the problem studied interpretation. Hermeneutic phenomenology is used as a critical analysis-reflective and interpretive of the text. Women in this study as a form of reality politics into the text to be interpreted, not only interpreted as a number, but further research is expected to reveal how the women go beyond the activities of the structure of power in the political realities of society so that they get the same opportunities in politics.

Hermeneutic phenomenology has the virtue of a method, whereby this method can be done in a comprehensive approach to the concepts and facts emerge. The interpretation offered an opportunity for researchers to explore the facts and concepts. At the end of this hermeneutic phenomenological method delivers the researchers to rational thinking and argumentative in sorting out facts and concepts that manifested itself not as an object but as a subject under study so as to provide a wealth of knowledge for researchers in uncovering the true meaning. Eidetic reduction in hermeneutic phenomenology allows research to reveal the meaning of which is not only visible on the surface of the political realities (Hikmawan, 2020). Thus the hermeneutic phenomenology as a method considered appropriate in the present study in order to get the essence (eidos) which in fact became a research question in this study (Hikmawan, 2014, 2017).

The data collected in this study comes from the first, in-depth interviews conducted (depth) on the informant who linked understand this context Kyai as pesantren leaders became a subject in the interview this time. Second, the observation by observing the phenomenon in order to obtain the data from the first source. The observations were made related to the structure of Kyai influence in the public sphere and Banten district administration. Third, the analysis of literature do is a study related to previous research that has been studied as well as from studies on particular offerings culturally in Banten. To maintain the validity of the data, researchers used the data triangulation technique. Triangulation is checking power back to the correctness of the data and their interpretation (Arikunto, 1998). The literature states that there are four triangulation techniques that can be used in research. First triangulation with the source, comparing and checking the degree of confidence in information obtained through time and different tools. Second, the triangulation method that can be applied with a view of checking the degree of confidence discovery research some power collection techniques or checking the degree of confidence multiple data sources with the same method. Third, triangulation with the investigator which utilize other researcher or analyst for the purposes of checking back in the degree of confidence of the data. Fourth,

\section{Results and Discussions}

Some public entities in Indonesia have a certain social construction involving Kyai figure. As the region has much in common, including placing Kyai as an intellectual in the field of Islamic religious sciences. Kyai a role model should be respected (Bahar, 2014), not only by his disciples (students) but also by society. Research (Horikoshi, 1987) mentions that Kyai a charismatic leader in the field of religion, he is fluent, and has the ability to careful in reading the minds of their followers. The other characteristics of the Kyai are forthright, bold, and forthright in 
attitude, and even as an expert he is far superior to the scholars in applying the principles of ijtihad (recognize the teachings of Islam logically). What are the findings of (Horikoshi, 1987) aligned with (Dhofier's, 1982) which saw Kyai an honorary degree for something that is considered sacred. Kyai title also honors for the elderly, as well as an expert for an Islam / have schools and teaching classics. Kyai notch as stated above can be found in some regions that have a tradition of boarding school education is still thick as the region "Horse hooves" in East Java, Madura, West Nusa Tenggara, a half of Central Java, and West Java. Differences between the position Kyai-region lies in the degree of influence and how to perform other functions in addition to religious leaders in the political and social dynamics of the community. Some studies were able to write the Kyai's role as a political broker,

Kyai in hierarchy of environmental education Boarding School. The hierarchical structure of the highest levels of the Guardians, Abuya, Kyai, Ustadz, and Pupils. Educational hierarchy is based on the level of understanding of religious knowledge, piety, and the ability to manage the patron-client relationship in stages. Muslim Research et al (2015) provide information that the capability of running the dichotomy of worldly and religious affairs (hereafter) to determine a person entered the hierarchical levels in question. This means that a guardian as hierarchy shoots will give a very small portion of the world affairs than affairs of religion in everyday activities. Likewise happens to give students more time for a larger part of world affairs than affairs of the hereafter.

The hierarchy structure of education at the boarding school environment in Banten region is dominated by the traditional Salafi pesantren Pesantren. The structure of the hierarchy is open to students until Kyai position. Each individual can be students, Ustadz, until Kyai gradually by running the activities and rituals that have been determined. To be able to rise to the next level, one should also run the patronclient relationship. Much like the cells of social construction. An Ustadz students can be when they are in senior positions (based on the ability to perceive religious knowledge and have practice time learning much longer than other students). Ustadz has students as disciples. Ustadz as teachers notch technical groups of informal learning in the boarding school. An Ustadz still must learn to deepen the religious knowledge of Kyai. Ustadz will rise if the level is Kyai existing students who become Ustadz.

Ustadz transformation into Kyai has to touch it to someone who is in a position senior Ustadz based on the ability of religious understanding and experience of time. A pattern like this will continue until the highest level. A mayor has pupils that Abuya. An Abuya has pupils that group Kyai. Kyai has pupils that Ustadz groups, as well as Ustadz who have few students. However, this kind of hierarchical structure is closed to the position Abuya and the Mayor. Not everyone had the opportunity to become Abuya and the Mayor. Only those who have lineage owner and founder of a boarding school can be Abuya. Even the mayor barely designation was given to those who are still alive. Only the great scholars who have died who received the title of mayor of the local community.

Kyai in Banten has a basic position as a religious leader who has students some Ustadz. Kyai Someone should build a career from the ground as a student regardless he has the lineage of a large Kyai or not. Over the development time, socio-political dynamics in Banten has put Kyai not just a religious studies teacher and caregiver Ustadz and Pupils at boarding school. Kyai has another role and influence in society. (Tihami, 1992) on the Kyai and Jawara in Banten give the results of a study that the knowledge of religion, the power of magic, and leadership pattern 
has formed a considerable influence on the Kyai and Jawara. Kyai influence on society has already begun in the struggle for the independence movement. Kyai able to appear as a scholar and "umaro" in the communities. History records several major Kyai like KH.Tubagus Ahmad Chatib able to become the first resident in the territory of the Residency Banten.

Other names that Brig KH.Sjam'un as the leader of freedom fighters, KH. Tb.Abdoel Halim as Regent Pandeglang, KH.Abdul Fatah Hasan as a member BPUPKI. Not only the leaders at the highest levels of government in the area, yet the underlying positions as the district officer, district, and head of the police force, mostly filled by the Kyai (Suharto, 2001). In the study (Suharto, 2001), the appearance of the ulama (represented by the figure of Kyai) in Banten local politics is a business in which they have been destroyed by the fighting after the position of Dutch colonialism. People want the appearance of the scholars as to the commander of the believers so that the vacuum of government in the early days of independence is the best opportunity for the scholars to show again as "umaro". The desirability group of scholars as the leader of the regional administration in Banten is a result of its ability to defend the interests of the people since the era of colonialism. Kyai became the leader of a small army unit that contains the students who are ready to fight against government abuses of colonialism. Boarding school environment not only as a means of informal education but became the center of propaganda, scholars consolidation arena champions and builders institutions caring for the oppressed people through moral and material assistance food. Kyai as pesantren leaders certainly has a positive effect on the existence of pesantren in the middle of residential areas (Fadhilah, 2011).

Colonial Government Kyai well aware of the strategic role in society. So they made a maneuver to separate Kyai role in public life. Colonial Government began to introduce a modern system of government bureaucracy. The influence and authority of the bureaucracy in larger units to be able to control people's lives as a policy field crops, application of the law of the colonial state in relation to civil society, taxation, trade controls, and more. Colonial Government sends leaders of the central civil service to fill positions including leader of government bureaucracy. Norms and values it tries to be separated from the horizontal relationships in the community. At this point, the degradation of Kyai role in public life in Banten by (Suharto, 2001) due to the efforts of the colonial government made gradually, in addition to several events that show their repressive policies against Kyai outspoken resistance. Kyai but still has its own place in public view. Its main activities as a religious studies teacher and leader of the Pesantren keep running. Pesantren still run social functions.

The golden age of Kyai performs its role as "umaro" in Banten in the early era of independence halt when the national political spectrum is in control of the leadership of President Suharto. Pancasila as the sole principle of policy implementation, simplifying the political groups, the hegemony of the power of the military-bureaucratic-Golkar, and the state policies that tend Islamophobia had an impact on the changing role of Kyai in Banten, not least Banten. Kyai was shaped by the political system into a state agency for the success of government programs. Even for a program that remains controversial to those who believe as the Family Planning Program contraceptive use, or prohibition of religious symbols in public spaces, Kyai still has to tell the good of the community. Kyai becomes a tool of legitimacy on government decisions aimed at strengthening the power of the regime. Kyai lined up into knots pollster for Golkar in every electoral victory of the New Order era. How the government to rake Kyai form of repression or cooperative. 
The government uses the instruments funding for Islamic Schools to control and control of Kyai influence. The government will carry out arrests and disappearances without the judicial process against Kyai who do not follow the instructions of the ruling regime. Stereotypes as a lackey of the PKI or the Islamic State of Indonesia movement establishing a flavor in the state's repressive measures against Kyai in Banten. Kyai lined up into knots pollster for Golkar in every electoral victory of the New Order era. How the government to rake Kyai form of repression or cooperative. The government uses the instruments funding for Islamic Schools to control and control of Kyai influence.

The government will carry out arrests and disappearances without the judicial process against Kyai who do not follow the instructions of the ruling regime. Stereotypes as a lackey of the PKI or the Islamic State of Indonesia movement establishing a flavor in the state's repressive measures against Kyai in Banten. Kyai lined up into knots pollster for Golkar in every electoral victory of the New Order era. How the government to rake Kyai form of repression or cooperative. The government uses the instruments funding for Islamic Schools to control and control of Kyai influence.

The government will carry out arrests and disappearances without the judicial process against Kyai who do not follow the instructions of the ruling regime. Stereotypes as a lackey of the PKI or the Islamic State of Indonesia movement establishing a flavor in the state's repressive measures against Kyai in Banten. The government uses the instruments funding for Islamic Schools to control and control of Kyai influence. The government will carry out arrests and disappearances without the judicial process against Kyai who do not follow the instructions of the ruling regime. Stereotypes as a lackey of the PKI or the Islamic State of Indonesia movement establishing a flavor in the state's repressive measures against Kyai in Banten.

The government uses the instruments funding for Islamic Schools to control and control of Kyai influence. The government will carry out arrests and disappearances without the judicial process against Kyai who do not follow the instructions of the ruling regime. Stereotypes as a lackey of the PKI or the Islamic State of Indonesia movement establishing a flavor in the state's repressive measures against Kyai in Banten. After the collapse of the New Order, the role of Kyai in Banten experienced a shift. The reform era provides open space for Kyai to perform a strategic role in society without losing their autonomy. Unfortunately Kyai, not the only actor who has that opportunity. There are actors politicians, businessmen, and a group of champions who are at the same time compete to seize influence in society. (Hamid, 2010) on local politics in Banten show is to shift the role of cultural broker Kyai into a political broker.

On the other hand, the winner getting a stronger political role that is largely facilitated by the dynamics of the political system favorable position in the midst of a democratic transition and economic crisis situation of citizens. Kyai group stuck in the competition and preserve the power of local political relations with the group of Champions. Kyai does not have enough resources to build influence in society autonomously in order of procedural democracy that focuses on the popularity and ownership of capital. Meanwhile, Kyai is still faced with the norm for "istiqomah" maintain morale and propaganda movement-based theology. So the choice to be an actor in the political constructs impractical or directly involved in the decision making the process so dilemma. Kyai group uncertainty in the transformation of the political system in his capacity as a subordinate cause appears logical interest groups in the 
electoral event or mass support purposes. Nevertheless, the influence of Kyai not cracked swallowed the changing times and the social dynamics of politics.

\section{Kyai as a Social Agent}

The existence of Kyai in Banten is very vital. Kyai is a solicitor de problems for various problems that afflict the people. The problem-solving approach always refers to the religious provisions contained in Al-Corán and As-Sunnah. Various problems ranging from private affairs in a small scope such as family to national scale public affairs, Kyai always provide solution considerations. Local society calls it with the term looking for "Barokah" or "Nyareat" to Kyai every time it collides with world affairs that cannot be resolved through normal procedures. The influence of Kyai in Banten in such a way is not created through a simple process. The position of Kyai is not just a religious leader or a pesantren leader and then automatically has a big influence in the community. An academic explanation is describing the role of Kyai in social relations and power relations that are authentic traits in the area of Banten.

As stated earlier, the Pandeglang community is in a traditional agrarian order. It is not just a matter of agriculture as a foundation for citizen economy, but it is related to social interactions, perspectives, and political perceptions of the community towards something. Traditional agrarian societies have different patterns of social relations with communities in modern industrial areas or trade-in services. In traditional agrarian societies, community ties within the village are still very close. This bond will be seen from empathy and a feeling of affinity between citizens. One person who has difficulty will be assisted by many residents to provide help. The value of tolerance, mutual cooperation, and helping become capital in building togetherness in the life of the village community.

Rural communal life will focus on many similarities compared to differences. Similarities in aspects of livelihood, economic activity, education, religious life, and matters in private areas such as property owners are always sought to be carried out together. A person will become isolated when he has a difference in certain aspects. The next characteristic of the life of traditional agrarian societies is the bond to their culture and region.

A culture that is nurtured by the local community will be maintained as part of the norm and identity. Community culture will involve regional aspects. Places to stand, move, get the benefits of nature and rituals of worship are one of the instruments of carrying out a recognized culture. So that traditional agrarian societies will not leave the village where they live too far to cross cities, unless they have been influenced by the value of modernity. A traditional agrarian society was so religious. Maintenance culture will go hand in hand with the implementation of religious activities. Islamic religion that developed in Banten society, has an impact on social life. Understanding of the value of religion in synergy with the custodian of culture and patterns of communal rural community life. Social activities In Banten hard everyday citizens released from a religious value. Thus, the figure of Kyai will have a special place in the public eye. Kyai advice and action not merely admonished religious leaders, but the basis for the preservation of the culture and characteristics of a communal society. Based on the demands of religion, Kyai would advise people to be a deep relationship with God (vertical) and worship the relationships between people (horizontal).

Based on the literature references on social structuration, (Bagguley, 2003; Clark, 1994; Giddens, 1987, 1990) in describing structuration not be equated with a bridle (constraint) but always curb (constraining) and delivered (enabling). Kyai 
group in its cultural influence deliberate action to accomplish their goals, at the same time act Kyai also have unintended consequences (unintended consequences) on the establishment of structures that have an impact on subsequent community action. Kyai action and discourse to the students and the local community are actually part of doing greatness.

Kyai was aware that the people should be directed to the appropriate kindness commands and avoid a ban on religion. Kyai with routine patterned giving lectures and examples of good deeds based on religious norms. What does Kyai not only to complete the tasks and obligations of connective teachings of the Prophet? However, there is the impact of unintended consequences (unintended consequences). This impact is formed from Kyai policy determination to consistently be on the road charity the good and prohibiting unjust society directs its activities. What was delivered Kyai will affect people's actions in the future.

Kyai greeting along with his actions is not a restraint (constraint). Kyai never imposes an encouragement to students or the public. But what do Kyai can be analyzed as one who always curb (constraining) and delivered (enabling) as what is revealed by (Giddens, 1990). Kyai use the arguments of religion as an instrument to make the students and the community are in a state must follow what it conveys. The structure described as a continuous flow behavior such as cognition, support or even break during the sense they awarded him (Giddens, 2011).

\section{Conclusion}

Kyai relationship patterns around the hierarchy kept waking repeatedly and maintained. Kyai as an agent that reproduces activity to express himself as an actor of social and political change in Banten. Kyai behavior would be understood as a command to perform an action that is considered to bring the truth and ideal conditions. Such relationships include various aspects of life in the social, political, and economic in Banten.

\section{Reference.}

Abdussalam, I. (2015). Reproduksi Kekuasaan Kyai Dan Blater Di Kabupaten Bangkalan. DIMENSI : Journal of Sociology, 8(1).

Arinia, I., Hikmawan, I. M. D., \& Ma'asan Mayrudin, Y. (2019). The Movement of Women with Disabilities on Indonesia's Legislative Election 2019.

Bagguley, P. (2003). Reflexivity contra structuration. Canadian Journal of Sociology, 28(2), 133-152. https://doi.org/10.2307/3341456

Bahar, M. S. (2014). KIYAI AND BEJINGAN: LOCAL POLITICAL ELITE AND THE HEGEMONIC CULTURE. Journal of Islamic Civilization in Southeast Asia, 3(1), 61-86.

Clark, J. (1994). Anthony Giddens: Consensus and Controversy. Social Forces, 73(1), 324. https://doi.org/10.2307/2579935

Dhofier, Zamaksar. 1982. Islamic Boarding School Tradition: Study of the Kyai Life View. LP3ES. p. 55. Jakarta.

Fadhilah, A. (2011). Struktur dan Pola Kepemimpinan Kyai dalam Pesantren di Jawa. Hunafa: Jurnal Studia Islamika, 8(1), 101-120.

Giddens, A. (1987). The Nation-State and Violence: Volume Two of a Contemporary Critique of Historical Materialism. Social Forces (Vol. 66). Polity Press. https://doi.org/10.2307/2578926 
Giddens, A. (1990). Structuration Theory: Anthony Giddens and the Constitution of Social Life. (I. J. Cohen, Ed.), Social Forces (Vol. 69). Macmilan. https://doi.org/10.2307/2579624

Hamid, Abdul (2010), The Kiai in Banten: Shifting Roles in Changing Times in Masaaki (eds) Islam in Contention: Rethinking Islam and State in Indonesia. Kyoto: Center for Southeast Asian Studies; Jakarta: Wahid Institute; Taipei: Center for Asia-Pacific Area Studies

Hamid, A. 2011. Pergeseran Peran Kyai dalam Politik di Banten Era Orde Baru dan Reformasi. Al Qalam. Vol. 28, No. 2, pp. 339-364.

Hikmawan, M. D. (2014). Politik Perbedaan: Demokrasi dalam Paradoks. Universitas Gdjah Mada.

Hikmawan, M. D. (2017). Politik Perbedaan: Minnoritas dalam Implementasi Kebijakan. Journal of Indonesian Public Administration and Governance Studies (JIPAGS), 1(1), 88-98.

Hikmawan, M. D. (2020). Consensual Democracy: A Challenge for Differentiated Citizenship. International Journal of Innovation, Creativity and Change. www.ijicc.net (Vol. 11). Retrieved from www.ijicc.net

Horikoshi., Hiroko., Kyai dan Perubahan Sosial, Jakarta: P3M, 1987.

Jannah, H. (2015). Kyai, Perubahan Sosial Dan Dinamika Politik Kekuasaan. FIKRAH: Jurnal Ilmu Aqidah Dan Studi Keagamaan, 3(1), 157-176.

Muslim, A., Kolopaking, L. M., Dharmawan, A. H., \& Soetarto, E. (2016). Dinamika Peran Sosial Politik Ulama dan Jawara di Pandeglang Banten. Mimbar, 31(2), 461-474.

Noeh, M. F., \& Othman, M. R. (2012). The Role Of Kyai In The 2004 Presidential Election: A Case Study In East Java, 27(2), 96-107.

Suharto. 2001. Banten in Revolution, 1451-1949: Process Integration In the Unitary State of the Republic of Indonesia (Disertation).Depok: UI.

Tihami, M.A. 1992. Kiyai dan Jawara in Banten: Study of Religion, Magic and Leadership in Pasanggrahan village (Thesis). Depok: UI.

Yasin. (2016). Kiai Lokal Antara Penghambat Dan Penyelamat Dalam Pelaksanaan Undang-Undang Perkawinan No. 1 Tahun 1974. Jurnal Pemikiran Hukum Dan Hukum Islam, 7(1), 57-73. 